\title{
Perspective Piece \\ Fumigation of Schools for COVID-19 Prevention in Nigeria: The Need for a Rethink
}

\author{
Abisoye Oyeyemi, ${ }^{1 \star}$ Adedotun Adesina, ${ }^{2}$ and Dimie Ogoina ${ }^{1}$ \\ ${ }^{1}$ Niger Delta University, Wilberforce Island, Nigeria; ${ }^{2}$ Nigerian Law School, Yenagoa, Nigeria
}

\begin{abstract}
The government of Nigeria ordered closure of schools to slow the spread of COVID-19 when the pandemic hit the country. About 5 months into the outbreak, secondary schools have been reopened to allow students to write their terminal examinations. Many state governments and school owners are fumigating their schools as a way of disinfecting the school environment and ensuring safe resumption of academic activities. We discuss the undue attention given to fumigation in this instance and stress the importance of addressing more beneficial and sustainable strategies to prevent COVID-19 in Nigerian schools.
\end{abstract}

COVID-19 has continued its unrelenting onslaught on the human race. However, man is fighting back and learning to live with the disease. As a result, many nations are easing lockdown and other restrictive measures enforced to limit movement in addition to implementing and promoting the observance of precautionary measures to slow the spread of the disease. ${ }^{1,2}$ As part of their prevention strategies or in preparation for reopening, governments and organizations in many countries are taking the initiative or are being pressured to invest scarce resources into fumigation of public places as a means of disinfecting and making such environments "safe" against COVID-19. ${ }^{3,4}$

Nigeria ordered secondary schools to reopen on August 4, 2020 after closure for about 5 months. The reopening was to start with students in classes overdue for their terminal examinations. ${ }^{5}$ The Nigeria CDC, in partnership with the Federal Ministry of Education, developed guidelines for schools to ensure safety of students and staff while carrying out academic activities. ${ }^{6}$ The guidelines stipulate a number of essential activities, based on the key strategies of physical distancing, hand hygiene, environmental cleaning, use of face masks, screening, isolation, and notification for further action. Although some state governments are supporting their schools to implement these strategies, others are paying lip service and not doing enough to prepare their schools for the safe resumption of academic activities. What seems to be an obsession of state governments and private school owners across the country in all geopolitical zones is fumigation. ${ }^{7-11}$ Although the national guidelines recommend fumigation as one of the measures to be taken for environmental safety and hygiene, ${ }^{6}$ fumigation seems to have become the cynosure, and it is dwarfing every other recommended measure to fight the disease. But of what value is spraying of classrooms and school premises in the prevention and control of COVID-19?

Infection with SARS-CoV-2, the virus that causes COVID19 , occurs primarily by direct contact with infected persons through their respiratory secretions or respiratory droplets, which may be expelled when infected persons cough, sneeze, talk, or sing. ${ }^{12,13}$ Respiratory droplets that are expelled in this process include the virus and can reach the mouth, nose, or eyes of a susceptible person, and result in infection. The

\footnotetext{
${ }^{*}$ Address correspondence to Abisoye Oyeyemi, Department of Community Medicine, Faculty of Clinical Sciences, College of Health Sciences, Niger Delta University, 1 CHS Road, Wilberforce Island,
} Nigeria 560103. E-mail: abisoyeyemi@hotmail.com second most important route is fomite transmission, which occurs when hands that touch contaminated surfaces and objects come in contact with the mouth, nose, or eyes. ${ }^{14}$ The virus has been shown to remain viable for hours to days on some fomites and surfaces. ${ }^{15,16}$ The likelihood of environmental contamination is high in healthcare settings where COVID-19 cases are managed, but because there is a possibility of surface contamination outside health facilities, the WHO advises using measures used in treatment centers in other places where large numbers of people gather, including religious houses, markets, and schools. ${ }^{17,18}$ Recommended measures for environmental cleaning and disinfection emphasize wiping potentially contaminated surfaces with cloth soaked in disinfectant solution after cleaning. Cleaning is an essential precursor of disinfection, as it removes or reduces the load of infectious agent, dirt, and other organic matter that may attenuate the potency of the disinfectant. ${ }^{17}$

Fumigation involves spraying disinfectant on surfaces to be decontaminated. The WHO strongly advises against fumigation or direct spraying with disinfectants of humans, as deleterious effects far outweigh benefits. ${ }^{17,19}$ Even in healthcare settings, where fumigation or other "no-touch" methods may be used for terminal disinfection, these are recommended only as supplements and not as a replacement for manual cleaning procedures. $^{20}$ SARS-CoV-2 is transmitted in places where people are active. What purpose is served by fumigating empty school premises that have had no human activities for months? Fumigation in this instance may kill or drive away harmful insects and other dangerous organisms, but there is no scientific evidence to show it to be useful for disinfecting against SARS-CoV-2.

In the face of dwindling financial resources due to the severe economic disruption caused by the pandemic, priority needs to be given to the most beneficial and cost-effective measures to fight the disease. Money earmarked for fumigation should be redirected to ensure implementation of evidence-based strategies recommended for schools. Many schools in Nigeria, particularly public schools, are overcrowded, ${ }^{21}$ and makeshift structures are needed to create additional classrooms to enable physical distancing. Government also needs substantial investment to ensure effective hand hygiene in schools. A recent survey found that only $36 \%$ of schools in Nigeria have access to basic water services, $16 \%$ to basic water and sanitation services, and $7 \%$ to combined basic water, sanitation, and hygiene services. ${ }^{22}$ It is imperative to provide handwashing stations with running water, soap, 
single-use hand towels, and hand sanitizers at strategic points in schools. More cleaners may need to be employed and additional equipment and items purchased to ensure adequate cleaning of surfaces. Quality fabric masks will need to be provided for staff and students while in school. The schools will need support to make special transport arrangements to ensure students and staff can commute to school safely. Educational materials conveying key messages about COVID19 prevention should be distributed to be liberally posted to reinforce precautions against the disease. For schools that lack sick bays, this is the time to establish them to ensure prompt attention for any sick student or staff member. In fact, the COVID-19 pandemic offers an opportunity to revamp Nigeria's weak school health programs.

There are many pressing needs to address to prevent COVID-19 transmission in schools in Nigeria. Fumigation is likely to give a false sense of invulnerability and detract from other more important safety measures. Resources devoted to it should be redeployed to proven, sustainable, and costeffective strategies that will prevent school outbreaks and help establish a health culture that will outlive COVID-19.

Received August 18, 2020. Accepted for publication August 19, 2020. Published online August 25, 2020.

Acknowledgments: Publication charges for this article were waived due to the ongoing pandemic of COVID-19.

Authors' addresses: Abisoye Oyeyemi, Niger Delta University, Wilberforce Island, Nigeria, E-mail: abisoyeyemi@hotmail.com. Adedotun Adesina, The Medical Centre, Nigerian Law School, Yenagoa, Nigeria, E-mail: adeshinadedotun@yahoo.com. Dimie Ogoina, Department of Internal Medicine, Faculty of Clinical Sciences, College of Health Sciences, Niger Delta University, Wilberforce Island, Nigeria, E-mail: dimieogoina@gmail.com.

This is an open-access article distributed under the terms of the Creative Commons Attribution (CC-BY) License, which permits unrestricted use, distribution, and reproduction in any medium, provided the original author and source are credited.

\section{REFERENCES}

1. World Health Organization Africa, 2020. WHO Urges Caution as Countries in Africa Ease Lockdowns. Geneva, Switzerland: WHO. Available at: https://www.afro.who.int/news/who-urgescaution-countries-africa-ease-lockdowns. Accessed August 13, 2020.

2. BBC News, 2020. Coronavirus: how lockdown is being lifted across Europe. BBCNews. Available at: https://www.bbc.com/ news/explainers-52575313. Accessed August 13, 2020.

3. Business Day, 2020. COVID-19: group writes NPA, calls for fumigation of ports to prevent spread. Business Day. Available at: https://businessday.ng/maritime/article/covid-19-groupwrites-npa-calls-for-fumigation-of-ports-to-prevent-spread/. Accessed August 13, 2020.

4. Naijasurf, 2020. COVID-19: house of Reps want fumigation of schools before re-opening. Naijasurf. Available at: https://naijasurf. com.ng/2020/05/25/covid-19-house-of-reps-want-fumigationof-schools-before-re-opening/. Accessed August 13, 2020.

5. Federal Ministry of Education, 2020. Exit Classes to Reopen August 4th. Available at: https://education.gov.ng/wp-content/ uploads/2020/07/EXIT-CLASSES-TO-REOPEN-AUGUST-4TH. pdf. Accessed August 13, 2020.
6. Federal Ministry of Education, 2020. Guidelines for Schools and Learning Facilities Reopening after COVID-19 Pandemic Closures. Available at: https://education.gov.ng/covid-19guidelines-for-safe-reopening-of-schools-learning-facilities/\#1. Accessed August 17, 2020.

7. The Guardian, 2020. Osun State government begins fumigation of schools ahead of students' resumption. The Guardian. Available at: https://guardian.ng/news/osun-state-governmentbegins-fumigation-of-schools-ahead-of-students-resumption/. Accessed August 13, 2020.

8. This Day, 2020. Enugu begins schools decontamination ahead of resumption. This Day. Available at: https://www.thisdaylive.com/ index.php/2020/08/01/enugu-begins-schools-decontaminationahead-of-resumption/. Accessed August 13, 2020.

9. Ijaw Nation Forum, 2020. Delta State Reassures Parents on Resumption, Begins Fumigation of Schools. Available at: https://www.ijawnation.org/delta-state-reassures-parentson-resumption-begins-fumigation-of-schools/. Accessed August $13,2020$.

10. Premium Times, 2020. WAEC: Kano government to fumigate 528 schools. Premium Times. Available at: https:// www.premiumtimesng.com/regional/nwest/406749-waeckano-govt-to-fumigate-528-schools.html. Accessed August 13, 2020.

11. The Guardian, 2020. School resumption: Zamfara government begins fumigation of 193 secondary schools. The Guardian. Available at: https://guardian.ng/news/school-resumptionzamfara-government-begins-fumigation-of-193-secondaryschools/. Accessed August 13, 2020.

12. Rothan HA, Byrareddy SN, 2020. The epidemiology and pathogenesis of coronavirus disease (COVID-19) outbreak. J Autoimmun 109: 102433.

13. Hamner $L$ et al., 2020. High SARS-CoV-2 attack rate following exposure at a choir practice - Skagit county, Washington, March 2020. Morb Mortal Wkly Rep 69: 606-610.

14. World Health Organization, 2020. Transmission of SARS-CoV-2: Implications for Infection Prevention Precautions: Scientific Brief. Geneva, Switzerland: WHO.

15. Chin AWH, Chu JTS, Perera MRA, Hui KPY, Yen H, Chan MCW, Peiris M, Poon LLM, 2020. Stability of SARS-CoV-2 in different environmental conditions. Lancet Microbe 1: e10.

16. van Doremalen $\mathrm{N}$ et al., 2020. Aerosol and surface stability of SARS-CoV-2 as compared with SARS-CoV-1. N Engl J Med 382: $1564-1567$

17. World Health Organization, 2020. Cleaning and Disinfection of Environmental Surfaces in the Context of COVID-19: Interim Guidance. Geneva, Switzerland: WHO.

18. World Health Organization, 2020. Considerations for SchoolRelated Public Health Measures in the Context of COVID-19: Annex to Considerations in Adjusting Public Health and Social Measures in the Context of COVID-19. Geneva, Switzerland: WHO.

19. Mehtar S, Bulabula ANH, Nyandemoh H, Jambawai S, 2016. Deliberate exposure of humans to chlorine-the aftermath of Ebola in West Africa. Antimicrob Resist Infect Control 5: 45.

20. Rutala WA, Weber DJ, 2013. Disinfectants used for environmental disinfection and new room decontamination technology. Am J Infect Control 41 (Supp/ 5): S36-S41.

21. Bashar S, Yasin M, 2020. A review of public secondary schools effectiveness in Nigeria: challenges and managing strategies. Int J Psychosoc Rehabil 24: 5220-5229.

22. National Bureau of Statistics, 2019. National Outcome Routine Mapping of Water, Sanitation and Hygiene Services Levels Nigeria: Summary of Survey Findings 2018. Available at: http:// www.washpmp.com/files/report_file/1_5d4c82ef-4c3c-4f8a92a1-52519f458993.pdf. Accessed August 16, 2020. 